\title{
EFFECT OF Curcuma Zedoaria EXTRACT ON TESTIS AND SEMINAL VESICLE WEIGHTS IN WHITE RATS
}

\author{
Rini Anggeriani \\ School of Health Sciences Abdurahman, Palembang, South Sumatra
}

\begin{abstract}
Background: The participation of men in family planning, particularly in Indonesia, is still lacking. Men dislike condom and vasectomy. Therefore, experts are trying to find a safe way for men by switching modern contraceptives to plants that can inhibit spermatogenesis. Plant that has an antifertility potential is Curcuma zedoaria (Berg) Rosc. This study aimed to examine the effect of Curcuma zedoaria extract on testis and seminal vesicle weights in white rats (Rattus norvegicus).

Subjects and Method: This was a completely randomized design (CRD) study with posttest only group design. A total of 24 male white rats were selected for this study and then randomized into two groups: intervention group and control group. The dependent variable was testis and seminal vesicle weights. The independent variable was Curcuma zedoaria extract. The rats in the intervention group were treated with Curcuma zedoaria extract in a dose of $300 \mathrm{mg} / \mathrm{kgBW}$ for 48 days. The data were analyzed by Independent Sample T-test.

Results: Testis and seminal vesicle weights were comparable and its mean difference was statistically non-significant indicating the success of randomization. Testis and seminal vesicle weights were lower in the intervention group than in the control group, and it was statistically significant.

Conclusion: The administration of Curcuma zedoaria extract can effectively reduce testis and seminal vesicle weights in male white rats.
\end{abstract}

Keywords: Curcuma zedoaria (Berg) Rosc, extract, testicular weight, seminal vesicular weight, male white rat

\section{Correspondence:}

Rini Anggeriani. School of Health Sciences Abdurahman, Palembang, South Sumatra. Email: Anggeriani_r@ymail.com. Mobile: 08127202482.

\section{BACKGROUND}

An effort carried out in the family planning program is providing contraceptive services. The contraceptive use in women reproductive age aims to prevent fertilization or fusion between male's sperm cells and female's ovum cells (eggs). The facility of contraception is aimed more for women, whereas it is still limited for men, so that the development of male contraception is far behind compared to female contraception (Prajogo, 2003 in Hartini, 2011).

The types of male contraceptive are condom and vasectomy. However, men dislike condom and vasectomy because they think that vasectomy will eliminate their might. Therefore, experts are trying to find a safe way for men without feeling that their might will be lost by switching to plants that can inhibit spermatogenesis.

Plants that are expected to be antifertility are Curcuma zedoaria Rosc. Curcuma zedoaria extract can affect spermatogenesis and spermatogenic cell layers of mice. Based on the result, there was a decrease in the number of spermatogenic cells in the seminiferous tubules of mice after being given Curcuma zedoaria extract, both spermatogonia, spermatocytes and spermatids compared to control. The higher the dose of Curcuma zedoaria given, the lower the number of spermato- 
genic cells. The decrease number of spermatogenic cells is probably caused by the disruption of the synthesis of testosterone in Leydig cells, so that the function of Sertoli cells is disrupted (Winarni, 1996 in Siswanti, 2003). The disruption of Sertoli cells can cause degeneration of spermatogenic cells. It occurs because one of the functions of Sertoli cells is to nourish spermatogenic cells. Spermatogenic cells cannot develop optimally due to malnutrition. The higher the dose of Curcuma zedoaria given, the more damaged Sertoli cells and the fewer spermatogenic cells formed.

Based on a study conducted by Siswanti et al. (2003), the Curcuma zedoaria rosc extract could change the structure of seminiferous tubules and affect sperm quality.

Based on the study sbove, Curcuma zedoaria rosc could cause infertility. The result of this study needs to be continued with studies on the active compound contained by Curcuma zedoaria rosc through extracts to see whether there is an infertility effect or not. This study aimed to examine the effect of Curcuma zedoaria extract on testis and seminal vesicle weights.

\section{SUBJECTS AND METHOD}

\section{Study Design}

This study was an experimental study by using male white rats as the experimental animals. The study design used to classify and intervene in the experimental animals was a Completely Randomized Design (CRD) with the posttest only control group technique.

\section{Population and Sample}

A total of 24 rats were selected as the sample of this study by using Systematic Random Sampling. The sample was divided into two groups: intervention group $\left(\mathrm{I}_{1}\right)$ that was given Curcuma zedoaria roscoe extract and control group $\left(\mathrm{C}_{0}\right)$ that was given $1 \%$ CMC solution orally. The data were analyzed by using Independent Sample T-test

\section{Curcuma zedoaria Extract}

$1 \mathrm{~kg}$ Curcuma zedoaria simplicia macerated with 1 liter methanol for 2x24 hours, then filtered and evaporated at $70^{\circ} \mathrm{C}$, and given ethanol to separate with active substances followed by waterbath.

\section{Stages of Intervention}

The control group was given CMC of $1 \%$ $2 \mathrm{ml}$ orally 1 times/day every morning for 48 days. The intervention group 1 was given Curcuma zedoaria Rosc extract at a dose of $300 \mathrm{mg} / \mathrm{kg} /$ day for 48 days. On the 49th day, the rats were sacrificed, then the testis and seminal vesicles were taken and the weight was calculated by using analytical scales.

\section{Ethical clearance}

This study had a strong scientific foundation, was useful to be carried out in a good manner, did not endanger and put the study subjects in a good place. The researcher believed that this study was ethical and has been approved to be carried out in the Mohammad Hoesin Hospital and the Faculty of Medicine of the University of Sriwijaya by the Chairman of the Assessment Team Prof. dr. Chairil Anwar, DAP\&E, SpParK, PhD and Chair of the Commission Prof. dr. Hermansyah, SpPD-KR.

\section{RESULTS}

\section{The Effect of Curcuma zedoaria on Testis Weight}

Giving Curcuma zedoaria extract to the male white rats for 48 days orally gave an effect to the testis weight. This effect can be seen in Table 1. 
Table 1. The result of the t-test test of testis weight inter-intervention group

\begin{tabular}{llllll}
\hline & Group & $\mathbf{N}$ & Mean & $\begin{array}{l}\text { Std. } \\
\text { Deviation }\end{array}$ & p \\
\hline $\begin{array}{llllll}\text { Testis } \\
\text { Weight }\end{array}$ & Control & 12 & 1.56 & 0.09 & 0.003 \\
\cline { 2 - 5 } & Intervention & 12 & 1.42 & 0.11 & \\
\hline
\end{tabular}

Based on Table 1, the mean in the control group was $1.56 \mathrm{gr}$ with SD by 0.09 . In addition, the mean in the intervention group was $1.42 \mathrm{gr}$ with $\mathrm{SD}$ by 0.11 . The difference in testis weight inter-group was o.14gr. Based on the result of t-test test, the $\mathrm{p}$ value $=0.003$, so it could be concluded that giving Curcuma zedoaria extract at a dose of $300 \mathrm{mg} / \mathrm{kgBB}$ had an effect to reduce the testis weight in male white rats.

The Effect of Curcuma zedoaria on Seminal Vesicle Weight

Giving Curcuma zedoaria extract to the male white rats for 48 days orally gave an effect on the seminal vesicle weight. It can be seen in Table 2.

Table 2. The result of the t-test test of seminal vesicle weight inter-intervention group

\begin{tabular}{lllllll}
\hline & Group & $\mathbf{N}$ & Mean & $\begin{array}{l}\text { Std. } \\
\text { Deviation }\end{array}$ & $\begin{array}{l}\text { Std. } \\
\text { Error }\end{array}$ & p \\
\hline Testis & Control & 12 & 1.36 & 0.13 & 0.377 & 0.007 \\
\cline { 2 - 6 } Weight & Intervention & 12 & 1.04 & 0.35 & 0.101 & \\
\hline
\end{tabular}

Based on Table 2, the mean in the control group was $1.36 \mathrm{~g}$ with SD by 0.13 . In addition, the mean in the intervention group was $1.04 \mathrm{~g}$ with SD by 0.35 . The difference in seminal vesicle weight inter-group was o.32g. Based on the result of t-test test, the $\mathrm{p}$ value $=0.007$, so it could be concluded that giving Curcuma zedoaria extract at a dose of $300 \mathrm{mg} / \mathrm{kgBW}$ had an effect to reduce the seminal vesicle weight in male white rats.

\section{DISCUSSION}

\section{The Effect of Curcuma zedoaria} Extract on Testis Weight

The result showed that the testis weight in the intervention group was $1.42 \mathrm{~g}$. The intervention group decreased compared to the control group which was 0.14g. The decrease in testis weight due to extract intervention was likely caused by the com- pounds contained in the extract which would affect spermatogenesis and cause atrophy.

Disruption of spermatogenesis can lead to testicular atrophy. The atrophy can be identified by measuring testis weight after the intervention (Lu, 1995 in Siswanti, 2003). This is consistent with Wahyuni (2006) which reported reduction in testis weight due to atrophy. It is a process of shrinking or decreasing the size of an organ or tissue from its normal form. Decreased cell size is caused by decreased number of cytoplasm and cytoplasmic organelles. It is associated with decreased metabolism.

In male animals, Gonadotropin Releasing Hormone $(\mathrm{GnRH})$ is secreted from the hypothalamus to stimulate the release of Lutenising Hormone ( $\mathrm{LH}$ ) and Follicle Stimulating Hormone (FSH) from the anterior pituitary. $\mathrm{LH}$ and FSH regulate testi- 
cular activity, LH stimulates Leydig cells to produce testosterone. FSH stimulates Sertoli cells for germ cell formation in spermatogenesis (Hernawati, 2001 in Habisukan, 2015). Decreased FSH and testosterone levels are likely to reduce testis weight (Wahyuni, 2006).

\section{The Effect of Curcuma zedoaria Extract on Seminal Vesicle Weight}

The current study found that seminal vesicle weight in the intervention group was $1.36 \mathrm{~g}$. The weight in the intervention group was $0.32 \mathrm{~g}$ lower than the control group. The decreased weight of the seminal vesicles might occur due to low testosterone levels which caused the inhibition of spermatogenesis in the testes. It also interfered with the development of the structure of the seminal vesicles and prostate cell production (Pathak, 2000 in Sari, 2014).

This is in line with (Martini, 1998 in Nugroho, 2007) that the inability of synthesis and secretion of GnRH by the hypothalamus causes failure of stimulation to the pituitary. Furthermore, the pituitary fails in the synthesis and secretion of FSH and LH. The failure of synthesis and secretion of both FSH and LH causes Leydig cells fail to synthesize testosterone.

Testosterone encourages growth, development, and functional activities of male genital organs, including different vases, penis, seminal vesicles, scrotum, to maintain viability of spermatozoa in the epididymis. Testosterone also maintains secondary male genital characteristics.

This study provided evidence that giving Curcuma zedoaria Rosc could cause changes in testis weight and histology and seminal vesicle weight in male white rats (Rattus norvegicus) for 48 days orally.

\begin{tabular}{c}
\hline REFERENCES \\
\hline $\begin{array}{c}\text { Ashfahani ED, Wiratmini, Sukmaningsih. } \\
\text { (2000). Motilitas dan Viabilitas }\end{array}$
\end{tabular}

Spermatozoa Mencit (Mus musculus L.) Setelah Pemberian Ekstrak Temu Putih (Curcuma zedoaria (Berg.) Roscoe.). Jurnal Biologi XIV.

Hartini (2011). Pengaruh Dekok Daun Jambu Biji Merah (Psidium guajava. L) Terhadap Jumlah Kecepatan Dan Morfologi Spermatozoa Tikus Putih Jantan (Rattus norvegicus). Universitas Andalas

Habisukan UH (2015). Perubahan Berat dan Struktur Histologi Testis dan Epididimis Tikus Jantan Sprague Dawley Akibat Pemberian Saponin Biji Klebet (Trigonella foenumgraecum L.). Program Pasca Sarjana Universitas Sriwijaya.

Murwati A, Nurrahmat (2000). Efek Hepatoprotektif Ekstrak Rimpang Temu Putih (Curcuma zedoaria Rosc) Pada Tikus Putih Jantan. Pharmacon 1 (1) $31-36$

Nugroho CA (2007). Pengaruh Minuman Beralkohol terhadap Jumlah Lapisan Sel Spermatogenik dan Berat Vesikula Seminalis Mencit. Universitas Widya Mandala Madiun.

Sari DP, Wiratmo (2014). Pengaruh Metanol, Fraksi N-Heksana, dan Fraksi Metanol Biji Pepaya (Carica papaya L.) terhadap Kadar Testosteron dan Bobot Organ Reproduksi Tikus Jantan. Universitas Jember.

Siswanti TPA, Okid TW (2003). Pengaruh Eksrak Temu Putih (Curcuma zedoaria Rosc.) terhadap Spermatogenesis dan Kualitas Spermatozoa mencit. BioSMART. 5(1): 38-42. Jurnal Biologi Fakultas MIPA UNS, Surakarta.

Wahyuni S (2006). Pengaruh Boraks terhadap Histologi Testis dan Epididimis Mencit Albino (Mus musculus). Program Pasca Sarjana Universsitas Sriwijaya. 